\title{
Regional climatic warming and associated twentieth century land-cover changes in north-western N orth America
}

\author{
Walter R. Skinner ${ }^{1, *}$, J acek A. Majorowicz ${ }^{2}$ \\ ${ }^{1}$ C limate Research Branch, Environment C anada, 4905 Dufferin Street, Downsview, Ontario M 3H 5T4, C anada \\ ${ }^{2}$ N orthern G eothermal, 105 C arlson C lose, Edmonton, Alberta T6R 2J 8, C anada
}

\begin{abstract}
Twentieth century (1900 to 1990) changes in annual surface air temperature (SAT) are compared with contemporaneous changes in annual ground surface temperature (GST) over an area extending from east of the Cordillera in north-western Canada, to Texas in the south-central United States. One of the largest SAT increases over the past century has occurred in the north-western portion of this study area. It also coincides (spatial regression coefficient $r=0.70$ ) with the largest positive GST anomaly in northern North America. However, there are large areas of Alberta, Saskatchewan, Manitoba and southern Northwest Territories that exhibit spatially coherent patterns of differences between SAT and GST warming. These differences appear to be related to twentieth century land-use and land-cover changes. The highest GST warming has been observed in large areas where extensive land-cover changes, such as the clearing of forests, increased forest fire activity, and conversion of prairie grassland to agricultural land, have occurred. It is hypothesized that land-cover change dramatically alters surface characteristics affecting the radiation budget and energy balance. The partitioning between sensible and latent fluxes is altered and the potential for land drying is increased. Calculated flux changes associated with land-cover change are comparable in magnitude with greenhouse gas radiative forcing. It therefore appears that through a step change in GST, land-cover changes have contributed to a portion of the observed SAT warming in this region.
\end{abstract}

KEY WORDS: Surface air temperature - Ground surface temperature - Ground temperature logs . North-western North America climate anomaly · Twentieth century land-use and land-cover changes

\section{INTRODUCTION}

The observed increase in globally averaged annual surface air temperature (SAT) over the past century (as measured at screen level $1.5 \mathrm{~m}$ above the ground surface) has been estimated between 0.3 and $0.6^{\circ} \mathrm{C}$ (Ellsaesser et al. 1986, J ones et al. 1986a, IPCC 1996). The temperature increase has been neither spatially nor temporally uniform. For example, some regions have warmed, while other regions have shown little change, or have even cooled (IPCC 1996). From 1895 to 1992, annual SAT warming over Canada was twice the global average at approximately $1.0^{\circ} \mathrm{C}$. Within

*E-mail: walter.skinner@ec.gc.ca western Canada the warming has ranged from $1.4^{\circ} \mathrm{C}$ for the Canadian north-western boreal forest region, and $0.9^{\circ} \mathrm{C}$ for the Canadian prairie region (Environment Canada 1995). For Canada, and the 2 western climate regions, there have generally been 3 distinct phases of SAT change: a warming from the 1890s to the 1940s, a cooling from the 1940s to the 1970s, and a resumption of warming from the late 1970s to the present (Environment Canada 1995). Most of this warming has occurred during winter and spring in the continental interior. Considerably less warming, and even cooling, has occurred over the North Atlantic and North Pacific, and oceanic margins of the N orth A merican continent. The greater warming of the continental interior may be caused by both the moderating effect of the oceans on the coastal margins and by positive 
feedbacks related to the hydrologic cycle. The feedbacks include the timing of freezing and melting, and changes in the areal distribution of ice and snow on land. In addition, Canada is located entirely in mid- to high latitudes where interannual and longer-term variations in atmospheric circulation patterns can have a considerable effect on regional climate. A persistent change in the normal jet stream track will affect temperatures differently in various regions of the country by changing the relative frequency of their exposure to warm and cold air masses.

Land-cover is the 'biophysical state of the earth's surface and immediate subsurface' while land-use 'involves both the manner in which the biophysical attributes of the land are manipulated and the intent underlying the manipulation' (Turner et al. 1995). Twentieth century land-cover change is caused mainly by changing human land-use. Changing land-cover, such as deforestation, results directly in evapotranspiration (Sagan et al. 1979, Dickinson 1991) and albedo (Dickinson 1991) changes and affects climate through alterations in energy and mass fluxes (Dale 1997).

Ground surface temperature (GST) changes in this and previous centuries are accurately preserved in subsurface temperature-depth profiles (Pollack \& Chapman 1993). Evidence from several North American studies has shown that GST warming trends, as described by geothermal methods, correspond well with SAT warming trends (Chisholm \& Chapman 1992, Wang et al. 1994, Deming \& Borel 1995, Harris \& Chapman 1995, M ajorowicz \& Skinner 1997a). M ajorowicz \& Skinner (1997a) found a high spatial correlation coefficient $(r=0.70)$ between SAT and GST warming patterns for the second half of the twentieth century in the Alberta subregion of the prairie provinces of Canada. The SAT/GST association suggests that the air and ground warming histories are closely related and that SAT warming is the main forcing factor upon GST warming. However, a recent comparison of SAT and GST changes over the last century has indicated large observed differences of up to $1.0^{\circ} \mathrm{C}$ in the boreal forest region and only minimal differences for the prairie grassland and aspen parkland transition region in Alberta (M ajorowicz \& Skinner 1997c). Recent subsurface temperature-depth measurements in southern Saskatchewan (Majorowicz et al. 1998) show magnitudes of GST warming greater than $2^{\circ} \mathrm{C}$ over the last century, well in excess of the SAT warming of approximately $1^{\circ} \mathrm{C}$ for the same time interval. In addition, recent borehole temperature analysis (Lewis \& Wang 1998) from deforested areas of western Canada (Vancouver Island) and eastern Canada (Ontario) suggest land developments that change surface climatic parameters, such as evaporation amounts, can contribute to regional climatic change.
A comparison of twentieth century SAT and GST warming over an area extending from east of the Cordillera in north-western Canada, to Texas in the south-central United States can assist in identifying the effects of local and regional land-cover changes upon climate in these environments. The purpose of this paper is to identify regions that exhibit spatially coherent patterns of differences between SAT and GST warming and to relate those difference patterns to twentieth century land-use and land-cover changes. This work expands on our previous work (Majorowicz \& Skinner 1997a,c) by more clearly defining and quantifying the spatial and temporal nature of the twentieth century climatic warming signal in north-western North America as forced by changing land-cover.

\section{BACKGROUND, STUDY AREA AND DATA}

2.1. G round warming from the analysis of well temperatures. Temperature variations at the earth's surface propagate downwards following the laws of conduction. The solid earth acts as a natural low pass filter to the downward propagating surface temperature changes in a wide range of frequencies. As a result, a profile of temperature with depth contains filtered information about past variations in climate. The propagation is a slow process due mainly to the low thermal diffusivity of the rocks (usually less than $1 \times 10^{-8} \mathrm{~m}^{2} \mathrm{~s}^{-1}$, where diffusivity $=$ thermal conductivity/heat capacity $x$ density). It has been demonstrated that for typical lithologies and related thermal diffusivities, the maximum temperature anomalies at depths of 25,80 and $250 \mathrm{~m}$ are related to surface temperature events of 10, 100 and 1000 yr ago, respectively (Harris \& Chapman 1997). Information about temperature anomalies with depth can be recovered by modeling methods and can be used as a proxy for past climatic variations (Lachenbruch \& M arshall 1986, Cermak et al. 1992, Majorowicz 1993, Shen et al. 1995a,b, Pollack et al. 1996, Gosnold et al. 1997, Harris \& Chapman 1997, Majorowicz \& Skinner 1997a,b,c, Lewis \& Wang 1998, Majorowicz $\&$ Safanda 1998).

The forward modeling method used to derive magnitudes of the ground surface warming from temperature logs (Lachenbruch \& Marshall 1986) was applied to some 80 wells in Alberta and Saskatchewan by Majorowicz (1993) and Majorowicz \& Skinner $(1997 a, b, c)$. This method has proven ideal for the identification of the GST warming in western Canada in this century since it is characterized by strong temperature anomalies with depth. However, for the reconstruction of longer GST histories of several centuries in duration, more complicated inversion techniques are required. 


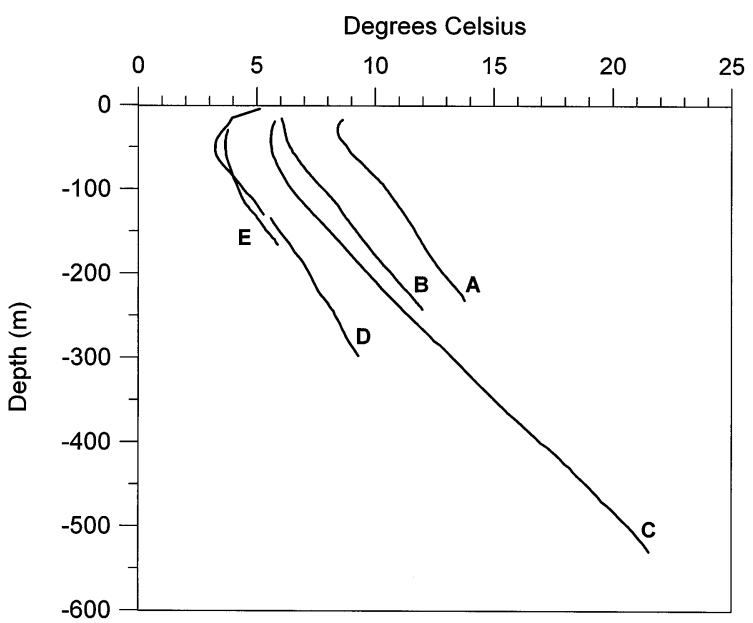

Fig. 1. Samples of temperature-depth data used for the inversions at individual sites in Alberta and Saskatchewan, Canada. Surface site conditions are: (A) mainly grassland (grazing systems in adjacent areas), (B) grassland mainly changed to grazing system, (C) grassland changed to field crops, (D) mainly boreal forest with clearcut in the well site with forest regrowth (2 temperature logs in 2 wells with different water static levels at 1 site), (E) mainly boreal forest with clearcuts for road construction and well drilling (area developed for oil sand operation)

For this study, GST histories were obtained by applying the functional space inversion (FSI) technique (Shen \& Beck 1991, Shen et al. 1995a, Majorowicz \& Safanda 1998, Majorowicz et al. 1998). A complete description of this technique as applied to our study area is given in A ppendix 1. Fig. 1 shows temperaturedepth profiles for 5 sample wells using this technique in the Alberta-Saskatchewan area of western Canada. These sites are characteristic of the various surface types in this large region and typify the variety of landuse and land-cover changes that have occurred in this century.

2.2. Land-cover changes and climate. Recent studies have shown that land-cover changes can be as important as increasing atmospheric greenhouse gases in climate change processes (Shukla et al. 1990, Bonan et al. 1992). The temporary or permanent removal of vegetation, through deforestation, forest fires, and grassland conversion for agriculture, can significantly change the surface properties of an area. A new surface geometry and al bedo affects the radiation budget, while changes in the thermal, moisture and aerodynamic characteristics affect energy balance partitioning between sensible and latent heat fluxes (Oke 1978, Ramakrishna \& Running 1995). If the area cleared is extensive enough, local, meso-, and large-scale changes in atmospheric dynamics and hydrology can occur through altered heat and water balances. Global losses from 1850 to 1980 in forest and grassland area were $601 \times 10^{6}$ and $1362 \times 10^{6}$ ha, respectively, while North America continent losses were $32 \times 10^{6}$ and 310 $\times 10^{6}$ ha, respectively (Houghton 1995).

Numerous model simulations and field studies have examined the effects of mainly tropical deforestation on regional climate (Dickinson 1989, Henderson-Sellers et al. 1993, Chalita \& Treut 1994, Polcher \& Laval 1994, Bonan et al. 1995, Copeland et al. 1996, Desborough et al. 1996, Zhang et al. 1996, Gash \& Nobre 1997). Several regional studies report increased surface temperature and decreased rainfall following clearing of land-cover (Dickinson \& Henderson-Sellers 1988, Lean \& Warilow 1989, Shukla et al. 1990). On a larger scale, the effects of land-cover changes are only recently being quantified. In a study of global vegetation changes, Ramakrishna et al. (1996), using AVHRR (Advanced Very High Resolution Radiometer) satellite data, identified the critical role vegetation cover plays in regulating surface temperature. Gash \& Nobre (1997) measured and modeled the local, meso, and large-scale climatic impacts of deforestation for large areas of the Amazonian tropical forest. They found that large-scale ecosystem changes have produced large alterations in the surface radiation balance and the partitioning of net radiation. On the local scale, reduced evaporation and increased sensible heat flux during the dry season produced higher daytime temperatures. Substantial clearing at scales over $50 \mathrm{~km}$ produced mesoscale circulation changes and differences in incoming radiation and cloudiness were observed. Kirchner (1984) simulated Bavarian catchment evaporation versus precipitation and identified as much as a $20 \%$ difference between totally reforested areas and areas converted to arable land.

Large-scale permanent changes to the land surface, especially natural grassland to farmland and clearcutting of the boreal forest, have occurred in the Canadian prairie provinces in this century. These changes were especially apparent during the drought years of the 1920s and 1930s immediately following a few decades of intensive land development and poor farm management in the southern prairie provinces (PFRA 1998). Also, Hayhoe \& Tarnocai (1993) analysed soil temperature data in discontinuous permafrost from sites along the Mackenzie River pipeline and found close to a $4.0^{\circ} \mathrm{C}$ increase in soil temperature as well as an increased depth of thaw at the sites where the surface vegetation had been disturbed.

Land-cover change over a large area that affects evaporation may also affect SAT and GST in surrounding areas to a lesser extent. Putnam \& Chapman (1996) determined that monotonic changes in vegetation can produce a change in the surface GST signal on the order of $1^{\circ} \mathrm{C}$ in the mid-western United States (Fig. 2b). This may explain observed GST changes in the areas 

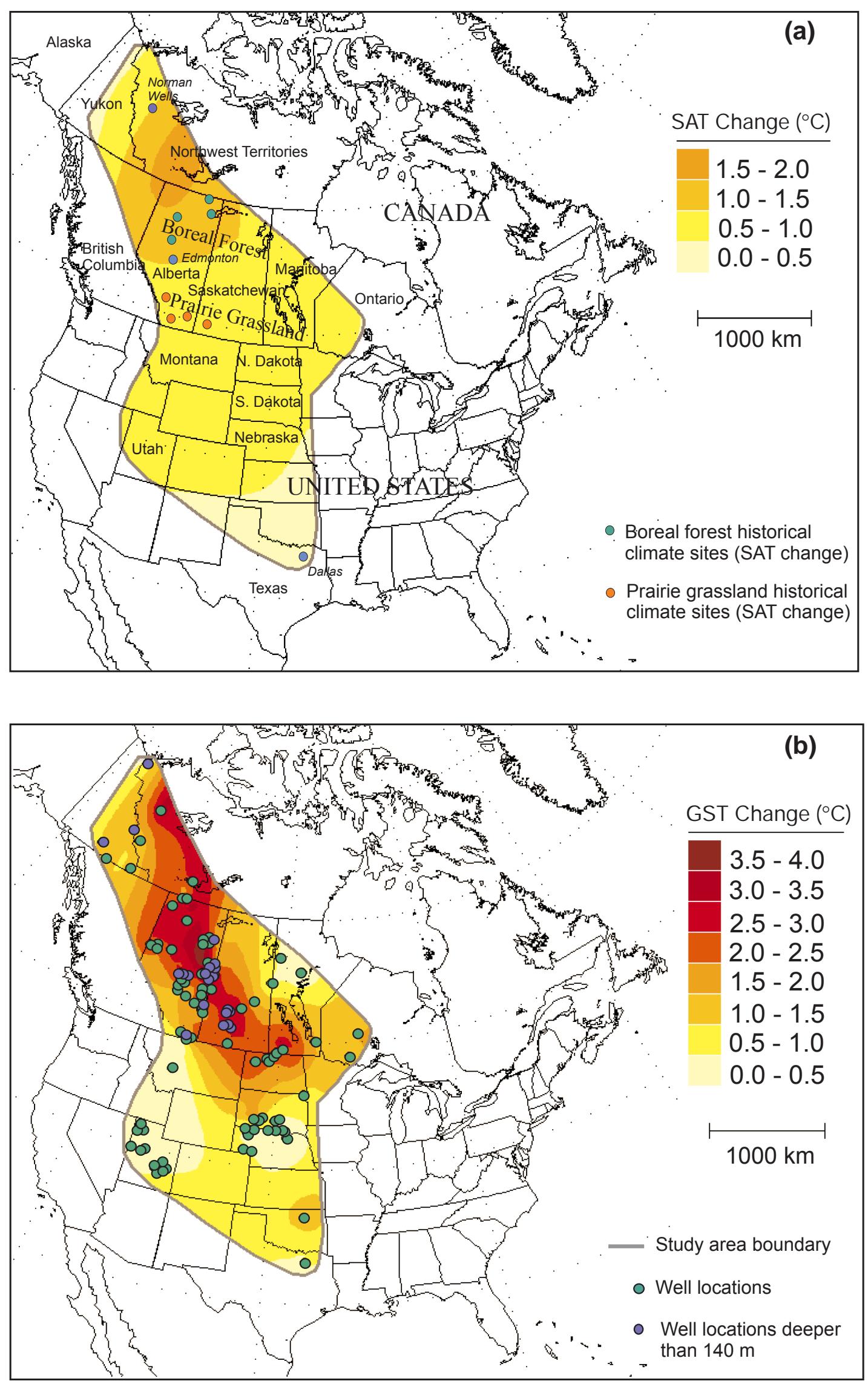


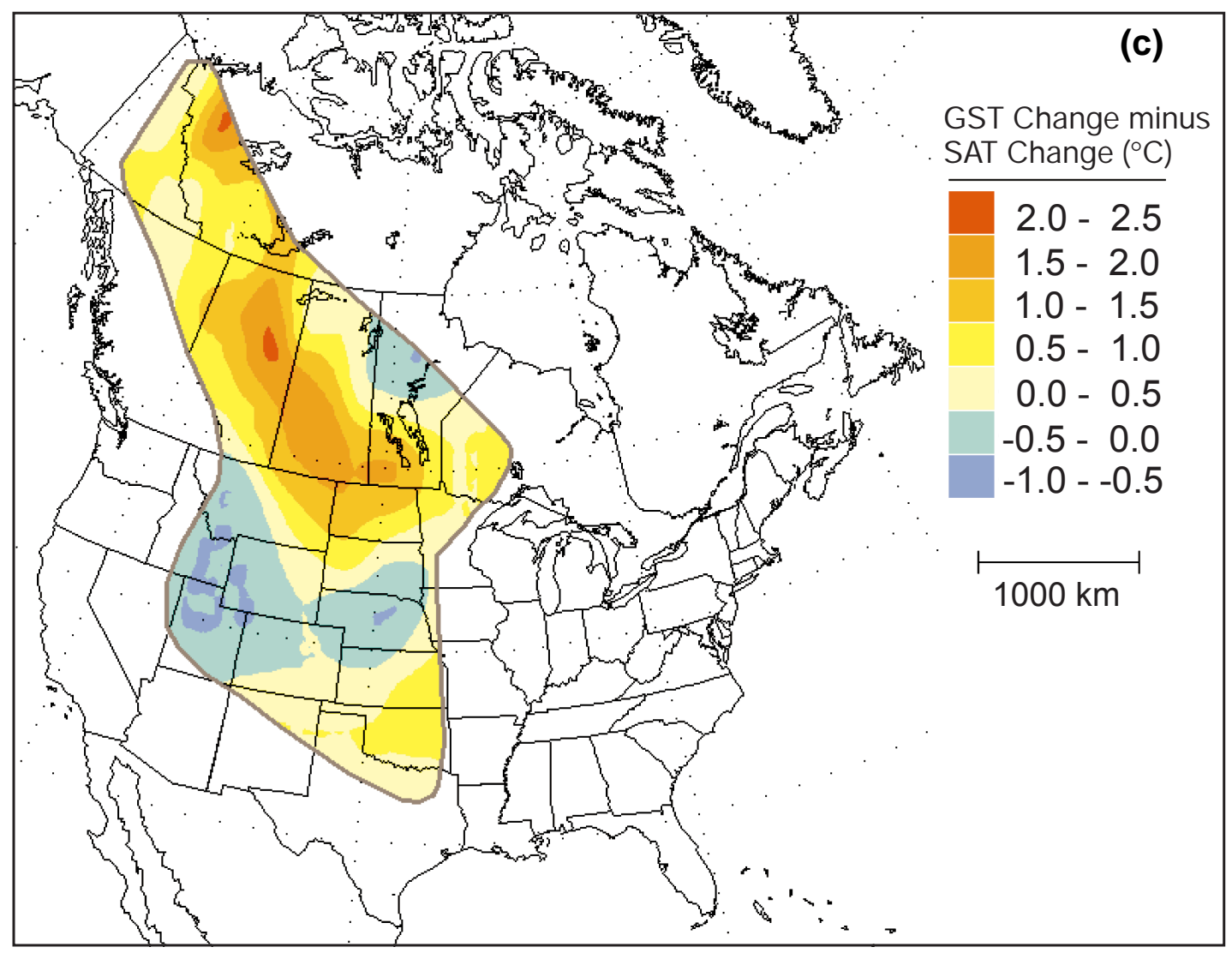

Fig. 2. (A bove and facing page.) (a) SAT change (1900 to 1990) with geographical names and with locations of the Canadian historical climate sites used for the comparison of twentieth century boreal forest and prairie grassland SAT changes, (b) GST change (1900 to 1990) with locations of wells used in the study, (c) GST change minus SAT change (1900 to 1990)

south of the boreal forest region where natural prairie grasslands were converted into grazing and crop lands earlier in this century. Lewis (1998), using borehole temperatures, has also shown that at sites in southern British Columbia where clearcutting has occurred and in the southern Yukon where the overlying land was permanently cleared by forest fire, GST increased at the time of deforestation. The elapsed times since deforestation ranged from 5 to $52 \mathrm{yr}$ and the increase in GST was $1.8^{\circ} \mathrm{C}$ on the northern Vancouver Island and $1.2^{\circ} \mathrm{C}$ in Yukon. Large magnitude warming would be expected from calculations for the transfer of heat energy due to transpiration in a forest with increased GST (Lewis 1998). Lewis (1998) outlined many factors which could contribute to differences in the amplitude of the observed GST changes including latitudinal differences and the proximity of the average temperature to $O \mathrm{E}^{\circ} \mathrm{C}$.

2.3. Study area. The study area was delimited by the distribution of well sites from the available temperature-depth profile data. The well site distribution used in this study and the outline of the study area are shown in Fig. 2b. This large region extends approximately $40^{\circ}$ of latitude and $30^{\circ}$ of longitude in mid-latitudes and has diverse geographical and climatological characteristics (see Fig. 2a for geographical names). Topographically, it consists mainly of relatively flat, open plains south of $53^{\circ} \mathrm{N}$ and boreal forest from about $53^{\circ} \mathrm{N}$ to the northern treeline. The majority of well data come from sites located on large flat regions of the Canadian Prairie Provinces and North-western Plains of the USA and are located in the former boreal forest or grasslands turned into grazing systems or farmlands. The study area is, with the exception of the higher elevation Utah area, located to the east of the mountains extending almost the entire length of the North American continent. The sites which were chosen for this analysis are considered to be representative of the surrounding regional conditions. Those sites with local clearcuts ( $50 \pm 20 \mathrm{~m}$ radius) around the well site were not considered.

The entire study area experiences a continental climate with generally cool to cold, dry winters and warm to hot, dry summers. There is considerable SAT and 
precipitation variability from north to south and from east to west. Mean annual SAT is $16^{\circ} \mathrm{C}$ in Dallas, Texas, $3^{\circ} \mathrm{C}$ in Edmonton Alberta, and $-6^{\circ} \mathrm{C}$ in Norman Wells, NWT (see Fig. 2a for locations). Total annual precipitation at these locations is 946, 474, and $183 \mathrm{~mm}$, respectively. Also, annual precipitation totals are generally higher in the eastern portions of the region when compared to the west. Autumn freeze and spring thaw take place latitudinally with large differences from north to south in seasonal timing and duration. Large-scale spatially consistent characteristics in both SAT and GST change over large areas in this region would indicate the influence of meso- to macroscale processes.

2.4. SAT and GST data. The SAT values used for mapping temperature change were taken from the global $5^{\circ} \times 5^{\circ}$ gridded monthly average data set (Climatic Research Unit 1992). Studies of large-scale temperature changes are usually aggregated into regular latitude/longitude boxes (J ones et al. 1986b, J ones \& Wigley 1990) in order to minimize spatial analysis problems caused by station turnover and large-scale averaging bias usually caused by regions with relatively dense station networks. These data are suitable for large area analysis and are recommended for use in anomaly form. SAT anomalies from the 1951 to 1980 reference period were calculated for the grid points within the study area. M agnitudes of SAT change were calculated at each grid point by linear regression over the complete 1900 to 1990 period and objectively interpolated using SPANS GIS (Fig. 2a).

Magnitudes of GST change from 1900 to 1990 were similarly calculated and objectively interpolated (Fig. 2b). The irregularly spaced data, characterized by extreme clustering, were transformed to a regular grid by the kriging method and then contoured using SPANS GIS. The majority of the GST change magnitudes used to generate the GST warming map originate from published Canadian data (Taylor et al. 1982, Beltrami et al. 1992, Beltrami \& Mareschal 1995, Majorowicz \& Skinner 1997a,b, Guillou-Frottier et al. 1998, Majorowicz \& Safanda 1998, Majorowicz et al. 1998). The United States values were also derived from published sources (Chisholm \& Chapman 1992, Deming 1995, Gosnold et al. 1997, Harris \& Chapman 1997).

The 8 SAT time series used for the comparison of twentieth century boreal forest and prairie grassland changes were taken from the Canadian historical climate database (Vincent \& Gullett 1998) (see Fig. 2a for station locations). Temperature records in this database have been rigorously quality controlled, assessed for homogeneity and adjusted where necessary to ensure regional representativeness (Vincent 1998). The data adjustments had the effect of removing some of the locally induced noise, or discontinuities, resulting from changes in observing programme, instrumentation, site conditions, and other non-climatic factors.

Historical SAT data, whether used as single station series or objectively interpolated onto a regular grid, represent measurements originally made at airports or agricultural stations. Instrument compounds are located over natural grassed surfaces to maintain national observing consistency. Changes in the immediate vicinity of the instruments have been considered and adjustments have been made to ensure time series homogeneity. In general, the surface characteristics immediately surrounding the instruments are not representative of the larger regional landscape characteristics that the temperature series are designed to represent, especially in forested regions. On the other hand, GST data have different site observational characteristics. They are located in natural areas where land-use and land-cover changes have occurred in this century (Fig. 1).

\section{RESULTS}

\subsection{Comparison of SAT and G ST change}

Spatial patterns of SAT and GST warming for the period 1900 to 1990 over mid-western and northern North A merica are compared (Fig. 2). The SAT warming map (Fig. 2a) identifies twentieth century warming magnitudes at screen level ( $1.5 \mathrm{~m}$ above the ground) of less than $0.5^{\circ} \mathrm{C}$ in the southern portions of the region, between 0.5 and $1.0^{\circ} \mathrm{C}$ throughout most of the Great Plains of the United States into the Canadian prairies, and 1.0 to $2.0^{\circ} \mathrm{C}$ in northern Alberta and southern Northwest Territories. The GST warming map (Fig. 2b) identifies twentieth century warming magnitudes at the ground surface of less than $1.0^{\circ} \mathrm{C}$ in the southern and north-eastern portions of the region, between 1.0 and $2.0^{\circ} \mathrm{C}$ throughout much of N orth Dakota and Montana and greater than $2.0^{\circ} \mathrm{C}$ in the southern prairie provinces and greater than $3.0^{\circ} \mathrm{C}$ in northern Alberta and southern Northwest Territories. A comparison of the SAT and GST warming maps identifies the regions of anomalous SAT warming $\left(0.5\right.$ to $\left.1.5^{\circ} \mathrm{C}\right)$ and GST warming $\left(1.5\right.$ to $\left.3.5^{\circ} \mathrm{C}\right)$ to be spatially coherent. Anomalous SAT and GST warming extends from north-western Canada (N orthwest Territories), through the Canadian prairie provinces, and into the north-western plains of the United States (North Dakota and Montana).

A spatial comparison between SAT and GST warming patterns characterized by identical grid samples extracted from each map (2757 pairs) shows a statistically significant correlation $(r=0.70, \alpha=0.01)$. This 
suggests that variations in SAT may be the primary factor causing variations in GST. Even though similar spatial patterns of warming have occurred, the GST warming is approximately $40 \%$ larger (greater than $2.0^{\circ} \mathrm{C}$ in northern Alberta) than the SAT warming when the SAT map is subtracted from the GST map (Fig. 2C). As noted earlier, some of the patterns shown in Fig. 2 can result from the objective interpolation procedure and the non-uniform spatial distribution of GST data as opposed to the regularly spaced SAT data. However, large-scale spatially coherent regional differences are evident, especially in areas with more comprehensive well coverage (i.e. Alberta, southern Saskatchewan, North Dakota, and Nebraska).

\subsection{C auses for differences between SAT and GST warming}

Various hypotheses for the existing differences between SAT and GST warming across different ecozones in Alberta, Canada have been tested ( $M$ ajorowicz \& Skinner 1997c). Data on soil temperature, hydrological piezometric surfaces, snowfall and moisture patterns, and land clearing and forest fires were analysed for large areas of Alberta that have not only been characterized by anomalous GST warming, but also have experienced widespread changes to the surface land-cover in this century. The observed GST warming cannot be explained by the insulating effect of increased snowfall and/or snow cover since slight decreases in both snowfall and snow cover have been observed throughout the Canadian Prairie provinces (Majorowicz \& Skinner 1997a, M ekis \& Hogg 1998). A longer active growing season, by about $7 \mathrm{~d}$ since the early 1960s in northern parts of North America, has recently been observed (Keeling et al. 1996, Myeni et al. 1997). At this time of year, large-scale, mid-latitude continental warming has strong positive feedback mechanisms forced by the large albedo difference between snow cover and snow-free ground. However, this lowering of the surface albedo would not account for GST warming being almost twice that of SAT warming.

A nother consideration is that the vertical component of the velocity of fluid flow is too low to account for the observed temperature variation with depth (M ajorowicz 1993). The geological media consist of flat, or nearly flat, sedimentary deposits with aquifers. Temperature logs repeated years apart confirm that the heat transfer is conductive only. The nature of the atmospheric and subsurface media for transferring heat energy has also been previously examined by comparing soil temperature (at $10 \mathrm{~cm}$ below the ground surface) and air temperature (at screen level $1.5 \mathrm{~m}$ above the ground sur- face) variations over the past $30 \mathrm{yr}$ (M ajorowicz \& Skinner 1997c). Both time series show similar interannual variations and magnitudes of change. It was also demonstrated that GST warming derived from well temperatures was largely affected by a step change event related to past land-cover changes that occurred long before the well was drilled and logged producing an increase in the climatic warming signal. The inversion technique has a smoothing effect on the GST history curve caused both by the superposition of climatic warming and more local-to-regional changes in climate due to the land-use history in the vicinity of the well.

\subsection{Western C anada temperature-depth profiles}

Fig. 3 compares the observed temperature logs from 22 wells greater than $140 \mathrm{~m}$ in depth in Alberta, Saskatchewan and NWT, Canada (Curve A) with the theoretically (Lachenbruch \& Marshall 1986, J essop 1990) calculated temperature-depth curves of surface mean annual warming of $1.4^{\circ} \mathrm{C}$ (Curve B: for northwestern boreal forest) and surface mean annual warming of $1.0^{\circ} \mathrm{C}$ (Curve C: Canada) forced by the linear increase ('ramp' function). The GST warming derived from well temperatures is consistent with a step change event related to land-cover changes in the past (M ajorowicz \& Skinner 1997c, Lewis 1998). The landcover changes have occurred well before the well was

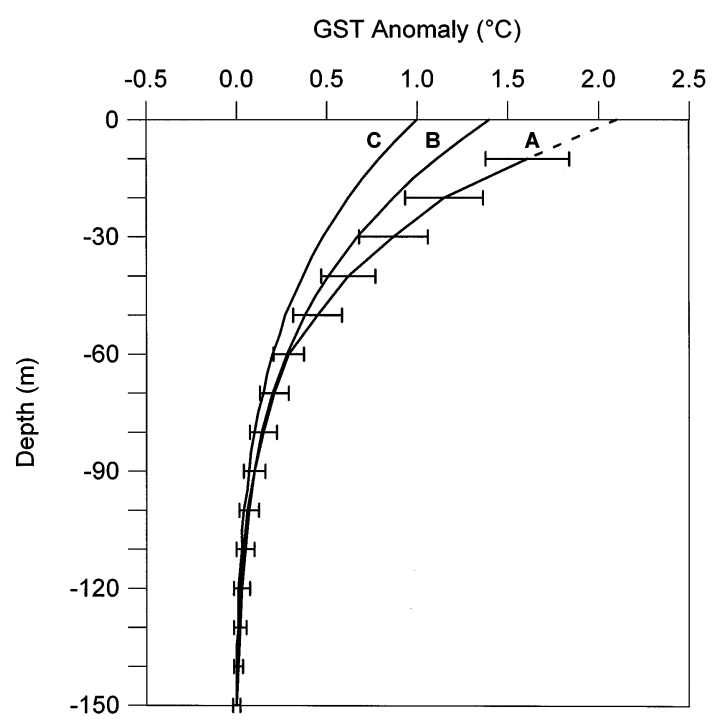

Fig. 3. Comparison of the observed and modeled temperature versus depth anomalies. Curve A: observations for 22 wells in the Canadian Prairie Provinces (error bars show 1 standard deviation). Curves $\mathrm{B}$ and $\mathrm{C}$ : the modeled anomalies with depth due to surface climatic forcing of $1.4^{\circ} \mathrm{C}$ warming in this century for the north-western boreal forest climate region and $1.0^{\circ} \mathrm{C}$ for Canada as a whole 


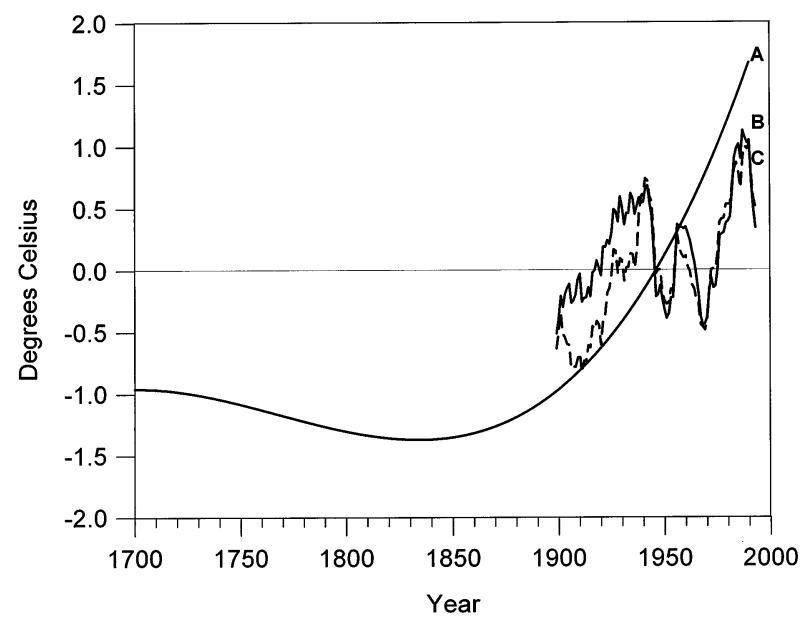

Fig. 4. Average annual GST history for 22 deep wells in Alberta, Saskatchewan and NWT, Canada (Curve A) plotted as departures from the 1900 to 1990 reference period and derived from temperature profiles with depth using the FSI (functional space inversion) technique. Average annual SAT histories from 1895 to 1992 also are also plotted as departures from the 1900 to 1990 reference period for (B) prairies and (C) north-western boreal forest climate regions. The minimum GST anomaly occurred in $1835, \pm 20 \mathrm{yr}$

drilled and logged. The effect is superimposed over the SAT warming signal and is smoothed due to the dispersive nature of the diffusive process upon the subsurface temperature field.

The inclusion of the Canadian curve (Fig. 3, Curve C) provides a useful reference for comparison with the anomalous climatic warming that has occurred in this century in western and north-western Canada, especially in the boreal forest region. The temperature anomaly was calculated every $10 \mathrm{~m}$ for the 20 to $150 \mathrm{~m}$ depth interval. The well temperatures come from wells with a large range of temperature-depth profiles (some as deep as $500 \mathrm{~m}$ ). This depth range was required to secure compatible GST histories for comparison with SAT histories.

As a first approximation, a thermal diffusivity of $0.8 \times$ $10^{-6} \mathrm{~m}^{2} \mathrm{~s}^{-1}$ and a thermal conductivity of $1.6 \mathrm{~W} \mathrm{mK}-1$ (calculated average effective conduction for clastic rocks in western Canadian Sedimentary Basin from measurements on rock and net rock evaluation) are used. The predicted temperature versus depth profile departs from the observations at a depth of about $60 \mathrm{~m}$. When a typical diffusivity of 0.7 to $0.8 \times 10^{-6} \mathrm{~m}^{2} \mathrm{~s}^{-1}$ for clastic rocks is assumed, modeling shows that this depth coincides with approximately $50 \mathrm{yr}$ ago. The departure of the observed and predicted temperaturedepth profiles indicates that GST warming exceeds that of SAT only during the second half of this century. Therefore, SAT warming alone is not sufficient explanation for the observed temperature-depth logs in the prairie provinces of western Canada in terms of conductive heat transfer.

Fig. 4 shows the average GST history from 1700 to 1995 (Curve A) plotted as departures from the 1900 to 1990 reference period as derived from the FSI (functional space inversion - A ppendix 1) technique of the observed temperature-depth profiles for the 22 deepest wells $(>140 \mathrm{~m})$ in Alberta, Saskatchewan and southern Northwest Territories. The well data were analysed for consistency and all GST histories indicated similar patterns characterized by modest cooling from 1700 until the mid-19th century followed by large magnitude warming. The magnitude of GST warming from 1895 to 1992 is greater than those of SAT warming for the major regions within western Canada, the prairies (Curve B) and north-western boreal forest (Curve C) (also plotted as departures from the 1900 to 1990 reference period). The GST history provides evidence of a lengthy warming trend that began in the mid-19th century (ca 1835, $\pm 20 \mathrm{yr}$ ) with an increase of approximately $2.5^{\circ} \mathrm{C}$ from that time until 1990. The GST warming trend was well underway when reliable instrumental SAT records began at the beginning of the twentieth century.

\subsection{G ST warming versus latitude}

Gosnold et al. (1997) showed a relationship between warming magnitude derived from well temperatures and latitude for the mid-western United States and southern Canada from 40 to $50^{\circ} \mathrm{N}$. They found that the GST warming magnitude correlates with latitude $(r=$ 0.825 ) while the SAT warming magnitude had a lower correlation level with latitude $(r=0.508)$. It was hypothesized that larger warming anomalies in the northern part of that region may be related to the changes in the soil moisture and latent heat during the freezing process. In the case of changes in moisture related to increases in precipitation, the soil temperature would be kept close to $0^{\circ} \mathrm{C}$ for a longer duration. The above interpretation differs from that of Lewis (1998) who found in different topographical and lithological conditions that the closer the average surface temperature of the area is to $0^{\circ} \mathrm{C}$ the smaller the GST warming. Both of these interpretations deal with the latent heat of freezing effect, however they do not take into account the balancing influence of the latent heat of thawing. In a closed system, heat of freezing should be equal to the heat of thawing. This explains the evidence that observed SAT changes are closely tracked by GST changes on the multi-decadal scale (Baker \& Ruschy 1993, M ajorowicz et al. 1998). The weak correlation of the GST warming magnitude with latitude in this region (Fig. 5) is likely related to the regional 


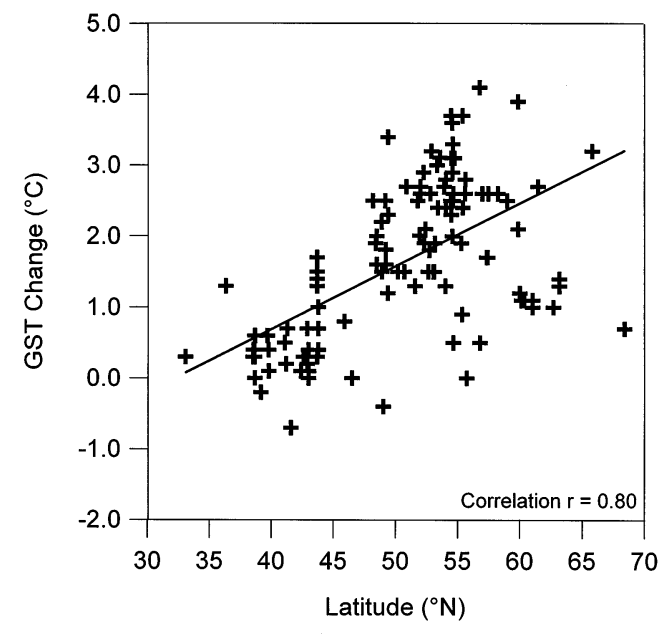

Fig. 5. Magnitude of the GST warming from the inversions of well temperature data with depth for the 1900 to 1990 period versus latitude for the western North America study area

change in the pace of the climatic warming signal (largest warming closer to poles).

M ajorowicz \& Skinner (1997c) noticed that changes in overall precipitation and piezometric levels of the near surface ground waters have not changed significantly over the past $40 \mathrm{yr}$. It has also been observed that the dependence of GST warming anomalies on latitude disappears when recent data of temperature versus depth from Manitoba are considered (GuillouFrottier et al. 1998). The northern M anitoba well temperatures show moderate warming magnitudes $(1 \pm$ $0.3^{\circ} \mathrm{C}$ ) north of $54.5^{\circ} \mathrm{N}$, approximately $1^{\circ} \mathrm{C}$ lower than that in Alberta and southern Saskatchewan ( $M$ ajorowicz 1993, Majorowicz et al. 1998) and North Dakota (Gosnold et al. 1997). The Manitoba data have been taken from undeveloped sites on the Canadian shield.

The data from western and northern Canada north of $49^{\circ} \mathrm{N}$ are combined here with the data from the Intermountain West High Plains, and portions of the Upper Midwest of the United States (see Fig. $2 b$ for the location of wells used in the study). Fig. 5 shows the relationship between the magnitude of GST warming for the 1900 to 1990 period at each well site and latitude $(r=0.80)$. Two groups of warming magnitude-latitude data are apparent. The first represents lower warming magnitudes south of $48^{\circ} \mathrm{N}$, while the second is characterized mostly by higher warming magnitudes north of $48^{\circ} \mathrm{N}$. It is important to note that these data are mostly from North Dakota, Saskatchewan and Alberta, and may not be entirely representative of the larger region. This south-north increasing gradient in GST warming magnitude is likely related to the similar SAT latitudinal warming gradient (Fig. 2a). However, large GST warming magnitudes of greater than $2.0^{\circ} \mathrm{C}$ have occurred mainly in the northern United States Great Plains and Canadian prairie provinces, between 48 and $58^{\circ} \mathrm{N}$. This is also a region that has been subjected to large-scale anthropogenic land-use and land-cover changes during this century.

\subsection{Regional land development and SAT/G ST}

Analysis of land development records in Alberta (Statistics Canada 1992) shows that farm land area increased dramatically over the first half of this century (Fig. 6, Curve A). It occurred mainly in the southern area of the province. Most of the development since mid-century has been in the northern boreal forest region especially over the past 20 to $30 \mathrm{yr}$. This coincides with the amplification of the regional temperature change (Fig. 6, Curve B) in the northern boreal forest just prior to the mid-point of this century. SAT warming for 4 climate stations in each of the 2 major climate regions (see Fig. 2a for station locations) are expressed as standardized anomalies for each station using the long-term mean and standard deviation (1900 to 1995). Time series for each region were averaged, and the prairie grassland series subtracted from that of boreal forest. A 2-phase regression model (Vincent 1998) identifies a statistically significant change point in 1937. The boreal anomalies, which had been generally less than the grassland anomalies $\left(-0.46^{\circ} \mathrm{C}\right.$ for 1900 to 1937$)$, became generally greater $\left(+0.24^{\circ} \mathrm{C}\right.$ for 1938 to 1995). The absolute value of the difference (boreal minus prairie) is $0.7^{\circ} \mathrm{C}$. This approach indicates

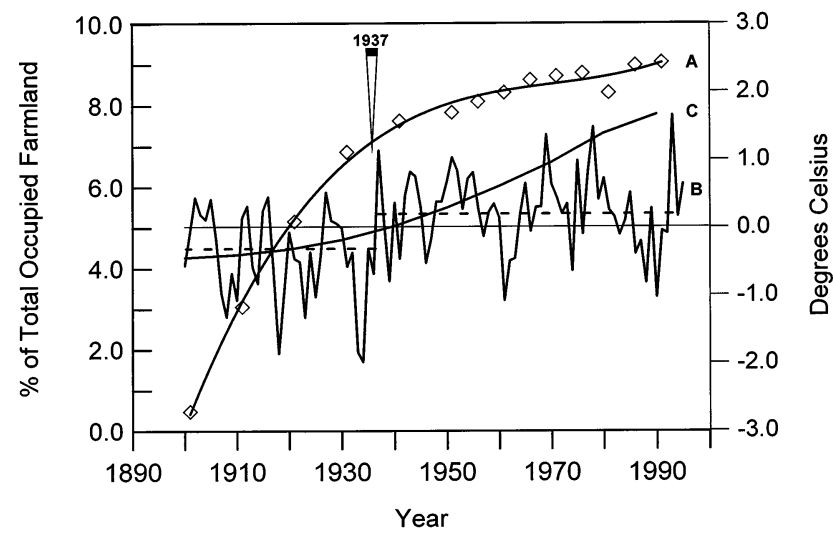

Fig. 6. Comparison of (A) the decadal changes in the area of the occupied farmland in Alberta in this century coinciding with (B) the average standardized anomalies of mean annual SAT for boreal forest minus prairie grassland, and (C) the average GST warming history for 22 deep wells in Alberta, Saskatchewan and NWT, Canada (as in Fig. 2). Note the statistically significant changepoint in 1937 identified by a 2phase regression of SAT anomalies in B; dashed horizontal lines indicate the SAT anomaly for each of the 2 periods 
a sudden shift in both the temporal and spatial patterns of SAT warming over this large region. SAT warming was relatively stronger in the south during the early part of this century and stronger in the north in the latter part. This pattern coincides approximately with the mid-century shift of human activity from southern to northern areas. The GST history, as shown in Fig. 4, Curve A, is also plotted for the period 1900 to 1990 (Fig. 6, Curve C).

\section{DISCUSSION}

The step change of average GST in western Canada (Alberta and Saskatchewan) is in the 1 to $2^{\circ} \mathrm{C}$ range (Majorowicz \& Skinner 1997c). The step change has also been identified for cleared land surfaces in British Columbia, Ontario and Quebec (Lewis \& Wang 1992, Lewis 1998), and in Cuba (Cermak et al. 1992). A step change in surface temperature propagates with depth as a function of time and is controlled by the diffusion constant, which causes the anomalous curvature observed in the temperature logs (Fig. 3). Anomalous warming has occurred in north-western and mid-western North America. It is especially evident in western Canada (northern Alberta and southern Saskatchewan) (Fig. 2a,b) where major land-cover changes have coincidentally occurred in this century (Fig. 6, Curve A).

Majorowicz \& Skinner (1997a,b) have shown a difference between the boreal forest sites in northern Alberta and the grassland sites in southern Alberta. However, recently acquired data from sites in Saskatchewan and North Dakota also show large warming magnitudes $\left(>2.5^{\circ} \mathrm{C}\right)$ in the developed grassland areas. Warming magnitudes are on average as high as those for the boreal forest region of northern Alberta. The comparison between SAT and GST warming (Fig. 2c) shows the difference is likely attributable to varying site characteristics. As previously stated, data derived from all original SAT sites represent measurements taken at grassed surfaces in the vicinity of the instruments. M ost of the SAT sites are at airports or at agricultural stations while the GST sites are located in natural settings of varying surface characteristics. In many cases, these sites have had a history of land development and other changes prior to well drilling and logging. If SAT stations existed at the well sites, it is likely that the SAT and GST variations would be similar in magnitude. The SAT and GST comparison in Fig. $2 c$ is evidence that the climatic warming in this century in the rural areas, that have been subjected to land development, has been greater than at the SAT sites that have not changed throughout the entire observation period.
The preceding paragraph suggests that land clearing affects GST changes, and it can also affect the temperature of the overlying air. Recently, Lewis (1998) determined the transpiration component of the heat budget for Vancouver Island biomass. This was done by calculating the amount of heat, $\mathrm{H}_{\mathrm{t}}$, required for transpiration of water from trees per unit area of ground from known parameters associated with tree growth as follows:

$$
H_{t}=P_{b} \times R_{t} \times H_{I w} \times d_{d}
$$

where $P_{b}$ is the biomass production rate, $R_{t}$ is the transpiration rate per amount of fibre growth, $\mathrm{H}_{\mathrm{Iw}}$ is the latent heat of water evaporated, and $d_{d}$ is the dry density of wood. Using approximate values for Vancouver Island biomass, Lewis (1998) calculated that the heat flux required for transpiration is about $3.5 \mathrm{~W} \mathrm{~m}^{-2}$; about $10 \%$ of the net radiation contribution to the ground surface heat budget. Using approximate values for the northern Alberta/Saskatchewan boreal forest biomass growth parameters (a typical range of forest biomass production for north-western Canada east of the Rocky Mountains, 1 to $5 \mathrm{~m}^{3} \mathrm{ha}^{-1} \mathrm{yr}^{-1}$; transpiration of water from trees, 200 to $300 \mathrm{k} \mathrm{k}^{-1}$ of dry fibre; latent heat flux at $20^{\circ} \mathrm{C}, 2.479 \mathrm{~J} \mathrm{~kg}^{-1}$; and the dry density of wood, $5.0 \times 10^{2} \mathrm{~kg} \mathrm{~m}^{-3}$ [Halliwel pers. comm. 1997]), the transpiration component of the heat energy flux of boreal vegetation is calculated to be in a range of that found for Vancouver Island, 2 to $6 \mathrm{~W} \mathrm{~m}^{-2}$. In comparison, since pre-industrial times the change in radiative forcing due to the enhanced greenhouse effect has been $2.45 \mathrm{~W} \mathrm{~m}^{-2}$ (IPCC 1996).

It was determined that the flux changes (as calculated from the Stefan-Boltzman Law for a black body surface) will affect GST (Geiger 1965). Using a surface temperature of $\mathrm{T}=0^{\circ} \mathrm{C}$ and a constant of $1.38 \times 10^{-23} \mathrm{~J}$ ${ }^{\circ} \mathrm{C}^{-1}$ (Putnam \& Chapman 1996), heat flow modeling indicates a step change in surface air temperature from 0.5 to $2.0^{\circ} \mathrm{C}$ in Alberta and southern Saskatchewan (Majorowicz \& Skinner 1997c). In comparison, the change in SAT due to radiative forcing associated with the greenhouse effect should be 0.6 to $0.7^{\circ} \mathrm{C}$ (approximately $0.27^{\circ} \mathrm{C}$ for each unit Watt increase in the flux). The modeled heat flux changes are in the range of the observed differences found between the SAT and GST warming (Fig. 2C) in north-western Canada.

\section{SUM MARY}

Evidence from borehole temperature inversion has suggested that, after SAT warming, permanent clearing of the land is the most effective and likely cause of the observed increases in GST. The most probable explanations for the observed GST warming are the 
anthropogenic activities of land-cover conversion from boreal forest, aspen, and natural prairie grassland cover to farmland and pastureland. A new surface geometry and albedo affects the radiation budget, while changes in the thermal, moisture and aerodynamic characteristics affect energy balance partitioning between sensible and latent heat fluxes. If the surface change is extensive enough, changes in atmospheric dynamics and hydrology can occur through altered heat and water balances. Objective analysis of contemporaneous SAT and GST changes in this century over a large area of north-western North America has identified spatially coherent patterns of differences that can be related to patterns in twentieth century land development and land-cover change. These differences are especially evident over large areas of north-western North America including the provinces of Alberta, Saskatchewan, Manitoba and southern Northwest Territories. The analysis of anomalous SAT and GST warming in areas where anthropogenic land-use and land-cover changes have taken place, and especially those formerly covered by the boreal forest, supports the hypothesis that flux changes associated with land-cover change are comparable in magnitude with greenhouse gas radiative forcing. On the other hand, in the Northwest Territories, and Cordillera part of Yukon-British Columbia, where there are only single well sites used in contouring of GST change, the identified differences between GST and SAT warming have not been related to patterns in twentieth century land-use and land-cover change.
Well sites, where GST data are measured for the reconstruction of the GST histories, have different site observational characteristics than SAT sites. In most cases, they are located in natural areas where land changes have occurred in this century. Well sites therefore record 'land change' related warming plus 'atmospheric' related warming. The SAT stations are located in open areas, and in many cases unlike the surrounding landscape, and record mainly 'atmospheric' related warming and possibly the feedback effects of the 'land change' warming in the regional context. Land-cover changes have caused anomalous ground surface warming and thus changes in the overlying air temperature, forcing further increases in SAT. With large tracts of the boreal forest being permanently deforested in this century, and natural grasslands being converted to farmland and rangeland, it is calculated that the change of the energy flux due to lower transpiration rates from the trees approximates that due to the industrial increase of greenhouse gases.

Preceding studies are consistent with the results of this study. Anthropogenic changes to the land surface, when superimposed upon greenhouse gas radiative forcing, likely explain the high temperature anomalies with depth and calculated GST warming identified here.

Acknowledgements. The authors are extremely grateful to $\mathrm{Dr}$ Barrie Bonsal of the Climate Research Branch, Atmospheric Environment Service, for his thoughtful and helpful comments. Also we would like to thank 2 anonymous reviewers for their constructive comments and suggestions.

A ppendix 1. Functional space inversion (FSI) technique

The degree of knowledge of both the measured temperature and the thermophysical parameters can be incorporated into the model in the form of a priori standard deviations. This technique assumes that heat transfer is only by conduction alone through a 1-dimensional, possibly heterogeneous medium. It is known from previous studies that the inversions are very sensitive to the a priori conductivity models. Due to the lack of core samples and thus measured conductivity data from the Alberta boreholes, the temperature profiles were subjected to a 'loose' inversion (Shen et al. 1995a) where part of the information is attenuated. This method ensures that the noise is not amplified. Noise suppression is achieved by assuming relatively high initial standard deviation of the a priori thermal conductivity model and the standard deviation of the measured temperatures.

Three versions of this method were considered by Majorowicz \& Safanda (1998) and Majorowicz et al. (1998): one with a priori conductivity and temperature standard deviation of $0.5 \mathrm{~W} \mathrm{mK}-1$ and $0.05 \mathrm{~K}$, the second with $2 \mathrm{~W}$ $\mathrm{mK}^{-1}$ and $0.05 \mathrm{~K}$, and the third with $4 \mathrm{~W} \mathrm{mK}^{-1}$ and $0.1 \mathrm{~K}$. The last 2 combinations ( $2 \mathrm{~W} \mathrm{mK}^{-1}, 0.05 \mathrm{~K}$ and $4 \mathrm{~W} \mathrm{mK}^{-1}, 0.1 \mathrm{~K}$ ) represent a higher uncertainty in the a priori information. When compared to the first combination $\left(0.5 \mathrm{~W} \mathrm{mK}^{-1}\right.$, $0.05 \mathrm{~K}$ ), they explain a greater degree of the measured temperature profile by changes in the a priori conductivity model (see Majorowicz \& Safanda 1998 and Majorowicz et al. 1998 for the detailed discussion of the constraints and its influence upon the inversion results). It does not strictly insist on the exact reproduction of the measured profile by the a posteriori model of the ground surface temperature history (GSTH) and thermophysical parameters. There is, however, a risk of misinterpreting the GSTH by inversion of the single logs with tight initial constraints on the borehole data (Shen et al. 1995b, Pollack et al. 1996). The limitations imposed by our data on 1-dimensional thermal conductivity model, as well as those imposed by the 3-dimensional heterogeneity of subsurface thermophysical properties (Shen et al. 1995a, Pollack et al. 1996, 1998), calls for the optimal inversion constraints that would effectively suppress noise without unduly suppressing the signal. 


\section{A ppendix 1 (continued)}

The main purpose of this paper is to focus on the interpretation of the GSTH regional warming patterns in this century (1900 to 1990). We have identified very high temperature anomalies of up to $3^{\circ} \mathrm{C}$ at upper depths (ca $100 \mathrm{~m}$ ) which are related to this century. The magnitude of these signals rapidly decreases with depth due to the dispersive nature of conduction. Relaxing of the a priori constraints is therefore justified and helps to mute the spurious histories without straying unrealistically from real conditions. Conditions which are too tight can boost small signals at depth out of proportion which can be close to measuring errors and conductivity uncertainties (Pollack et al. 1996, Majorowicz \& Safanda 1998).

For data used in this study, the combinations $\left(2 \mathrm{~W} \mathrm{mK}^{-1}\right.$, $0.05 \mathrm{~K})$ give more consistent GSTHs throughout the study area than do those of $\left(0.5 \mathrm{~W} \mathrm{mK}^{-1}, 0.05 \mathrm{~K}\right)$, however in some cases of the more simple monotonous lithology and related conductivity changes the latter were chosen (M ajorowicz et al. 1998).

The a priori model used has the following structure: thermal conductivity 1.2 to $2 \mathrm{~W} \mathrm{mK}^{-1}$ (mean $=1.6 \mathrm{~W} \mathrm{mK}^{-1}$ ), diffusivity 0.6 to $0.8 \times 10^{-6} \mathrm{~m}^{2} \mathrm{~s}^{-1}$, and heat production $2 \times 10^{-6}$ $\mathrm{W} \mathrm{m^{-3 }}$. A thermal conductivity of $1.6 \mathrm{~W} \mathrm{mK}^{-1}$ is the best estimate of average thermal properties of the shallow highly saturated clastic sediments (clays, shales, shale siltstone, high porosity saturated sands). A lower thermal conductiv- ity ( 1.2 to $\left.1.4 \mathrm{~W} \mathrm{mK}^{-1}\right)$ for the larger fraction of shales and clays has also been considered. The effect of the lower conductivity (and therefore diffusivity values) can be assessed. The GSTH for the lower assumed conductivity reveals a higher GST minimum shifted earlier in time by 20 to $40 \mathrm{yr}$ for the $1.2 \mathrm{~W} \mathrm{mK}^{-1}$ case, and by 10 to $20 \mathrm{yr}$ for the $1.4 \mathrm{~W}$ $\mathrm{mK}^{-1}$ case. The conductivity of $1.2 \mathrm{~W} \mathrm{mK}^{-1}$ and corresponding diffusivity $0.6 \times 10^{-6} \mathrm{~m}^{2} \mathrm{~s}^{-1}$ is the extreme minimum case (for low conductivity shallow clays and shales) discussed by Majorowicz \& Safanda (1998, Figs. 3a,b \& 5). Low conductivity coals or high conductivity quarzite sandstone fragments are rare and do not have much influence on the average effective conductivity. These variations are taken into account by assuming relatively high SDs in the initial a priori model as discussed in the previous paragraph. The model of heat production influences the results very little and is, together with the diffusivity, practically unresolved by inversion. In contrast, the conductivity and, of course, the GSTH are much better resolved.

The final judgement of the proper solutions is the fit of the calculated temperature anomaly profile to temperature anomalies based on measured data from wells. In all of the wells this was excellent. The misfits are commonly smaller than $0.05^{\circ} \mathrm{C}$ which is close to the practical error of temperature measurements in real well conditions (Harris \& Chapman 1995, Majorowicz et al. 1998).

\section{LITERATURE CITED}

Baker DG, Ruschy DL (1993) The recent warming in eastern Minnesota shown by ground temperatures. Geophys Res Lett 20:371-374

Beltrami H, Mareschal J C (1995) Resolution of ground temperature histories inverted from borehole temperature data. Global Planet Change 11:57-70

Beltrami H, J essop AM, M areschal J C (1992) Ground temperature histories in eastern and central Canada from geothermal measurements: evidence of climatic change. Paleogeogr Paleoclimatol Paleoecology (Global Planet Change) 98:167-184

Bonan G, Pollard D, Thompson S (1992) Effects of boreal forest vegetation on climate. N ature 359:716-718

Bonan GB, Chapin FS, Thompson SL (1995) Boreal forest and tundra ecosystems as components of the climate system. Clim Change 29:145-167

Cermak V, Bodri L, Safanda J (1992) Recent climate change recorded in the underground: evidence from Cuba. Paleogeogr Paleoclimatol Paleoecol (Global Planet Change) 98: 219-223

Chalita S, Le Treut H (1994) The albedo of temperate and boreal forest and the Northern Hemisphere climate: a sensitivity experiment using the LMD GCM. Clim Dyn 10: 231-240

Chisholm TJ , Chapman DS (1992) Climate change inferred from borehole temperatures: an example from western Utah. J Geophys Res 97:14155-14176

Climatic Research Unit (1992) World climate disc. Grid box temperature dataset. University of East Anglia, Norwich

Copeland J H, Pielke RA, Kittel TGF (1996) Potential climatic impacts of vegetation change: a regional modeling study. J Geophys Res 101:7409-7418

Dale VH (1997) The relationship between land-use change and climate change. Ecol Appl 7(3):753-769
Deming D (1995) Climatic warming in North America: analysis of borehole temperatures. Science 268:1576-1577

Deming D, Borel RA (1995) Evidence of climatic warming in northcentral Oklahoma from analysis of borehole temperatures. J Geophys Res 100:22017-22032

Desborough CE, Pitman AJ, Irannejad P (1996) Analysis of the relationship between bare soil evaporation and soil moisture by 13 land surface schemes for a simple non-vegetated site. Global Planet Change 13:47-56

Dickinson RE (1989) Modeling the effects of Amazonian deforestation on regional surface climate: a review. Agric For M eteorol 47:339-347

Dickinson RE (1991) Global change and terrestrial hydrology: a review. Tellus 42AB:176-181

Dickinson RE, Henderson-Sellers A (1988) Modeling tropical deforestation: a study of GCM land-surface parametarization. Q J R M eteorol Soc 114:439-462

Ellsaesser HW, M acCracken M C, Walton J J , Grotch SL (1986) Global climatic trends as revealed by the recorded data. Rev Geophys 24:745-792

Environment Canada (1995) The state of Canada's climate: monitoring variability and change. State of the Environment Report No. 95-1. M inister of Public Works and Government Services Canada, Ottawa

Gash JHC, Nobre CA (1997) Climatic effects of Amazonian deforestation: some results from ABRACOS. Bull Am Meteorol Soc 78:823-830

Geiger R (1965) The climate near the ground. Rev edn. Harvard Univ Press, Cambridge, MA

Gosnold W, Todhunter PE, Schmidt W (1997) The borehole temperature record of climate warming in the mid-continent of North America. Global Planet Change 15:33-45

Guillou-Frottier L, Mareschal J C, Musset J (1998) Ground surface temperature history in central Canada inferred from 10 selected borehole temperature profiles. J Geophys Res 103:7385-7397 
Harris RN, Chapman DS (1995) Climate change on the Colorado Plateau of eastern Utah inferred from borehole temperatures. J Geophys Res 100:6367-6381

Harris RN, Chapman DS (1997) Borehole temperatures and a baseline for 20th-century global warming estimates. Science 275:1618-1621

Hayhoe H, Tarnocai C (1993) Effect of site disturbance on the soil thermal regime near Fort Simpson, Northwest Territories, Canada. Arct Alp Res 25:1:38-44

Henderson-Sellers A, Dickinson RE, Durbidge TB, Kennedy PJ , M cGuffie K, Pitman AJ (1993) Tropical deforestation: model local- to regional-scale change. J Geophys Res 98: 7289-7315

Houghton RA (1995) Land-use change and the carbon cycle. Global Change Biol 1:275-287

IPCC (1996) Climate change 1995: the science of climate change. Houghton J T, M eira Filho LG, Callander BA, Harris N, Kattenberg A, Maskell K (eds). Cambridge University Press, Cambridge

J essop AM (1990) Thermal geophysics. Developments in solid earth geophysics series 17. Elsevier, Amsterdam

J ones PD, Wigley TML (1990) Global warming trends. Sci Am 263:84-91

J ones PD, Wigley TML, Wright PB (1986a) Global temperature variations between 1861 and 1984. Nature 322: 430-434

J ones PD, Raper SCB, Bradley RS, Diaz HF, Kelly PM, Wigley TML (1986b) Northern Hemisphere surface air temperature variations: 1851-1984. J Clim Appl Meteorol 25: 161-179

Keeling CD, Chin J FS, Whorf TP (1996) Increases activity of northern vegetation inferred from atmospheric $\mathrm{CO}_{2}$ measurements. Nature 382:146-149

Kirchner M (1984) Chapter 3. Influence of different land use on some parameters of the energy and water balance. In: Leith $\mathrm{H}$, Fantechi $\mathrm{R}$, Schnitzler $\mathrm{H}$ (eds) Interactions between climate and biosphere. Prog Biometeorol 3: 65- 74

Lachenbruch AH, Marshall BV (1986) Changing climate: geothermal evidence from permafrost in the Alaskan Arctic. Science 234:689-696

Lean J, Warilow DA (1989) Simulation of the regional climatic impact of Amazonian deforestation. Nature 342: 411-413

Lewis TJ (1998) The effect of deforestation on ground surface temperatures. Global Planet Change 18:1-13

Lewis TJ , Wang K (1992) Influence of terrain on bedrock temperatures. Paleogeogr Paleoclimatol Paleoecol (Global Planet Change) 98:87-100

Lewis TJ , Wang K (1998) Geothermal evidence for deforestation induced warming: implications for the climatic impact of land development. Geophys Res Lett 25:535-538

Majorowicz J A (1993) Climate change inferred from analysis of borehole temperatures: first results from Alberta basin, Canada. Pure Appl Geophys 140:655-666

Majorowicz J A, Safanda J (1998) Ground surface temperature from inversions of underground temperatures (functional space inversion technique) - Western Canadian Sedimentary Basin case study. In: Cermak V (ed) Special issue: heat flow and the structure of the lithosphere IV. Tectonophys 291:287-298

Majorowicz JA, Skinner WR (1997a) Anomalous ground warming versus surface air warming in the Canadian Prairie provinces. Clim Change 35:485-500

Majorowicz JA, Skinner WR (1997b) Anomalous ground warming versus surface air warming in the Canadian Prairie provinces. In: Cohen S (ed) Mackenzie Basin impact study report. Environment Canada, Downsview, p 107-111

Majorowicz J A, Skinner WR (1997c) Potential causes of differences between ground and surface air temperature warming across different ecozones in Alberta, Canada. Global Planet Change 15:79-91

Majorowicz J A, Safanda J , Harris R, Skinner WR (1999) Large ground surface temperature changes of the last three centuries inferred from borehole temperatures in the southern Canadian Prairies-Saskatchewan Global Planet Change (in press)

Mekis E, Hogg WD (1998) Rehabilitation and analysis of Canadian daily precipitation time series. Atmos Ocean 37: 53-85

Myneni RB, Keeling CD, Tucker CJ, Asrar G, Nemani RR (1997) Increased plant growth in the northern high latitudes from 1981 to 1991. Nature 386:698-702

Oke TR (1978) Boundary layer climates. Methuen and Co Ltd, London

PFRA (1998) Drought in the Palliser Triangle (a provisional planner). Prairie Farm Rehabilitation Administration, Calgary

Polcher J, Laval K (1994) A statistical study of the regional impact of deforestation on climate in the LMD GCM. Clim Dyn 10:205-219

Pollack HN, Chapman DS (1993) Underground records of changing climate. Sci Am J une 286(6):44-50

Pollack HN, Shen PY, Huang S (1996) Inference of ground surface temperature history from subsurface temperature data: interpreting ensembles of borehole logs. Pure Appl Geophys 147:537-550

Pollack HN, Huang S, Shen PY (1998) Climate change record in subsurface temperatures: a global perspective. Science 282:279-281

Putnam SN, Chapman DS (1996) A geothermal climate change observatory - first year results from Emigrant Pass in northwest Utah. J Geophys Res 101:21877-21890

Ramakhrishna R, Running SW (1995) Satellite monitoring of global land cover changes and their impact on climate. Clim Change 31:395-413

Ramakhrishna R, Running SW, Pielke RA, Chase TN (1996) Global vegetation cover changes from coarse resolution satellite data. J Geophys Res 101(D3):7157-7162

Sagan C, Toon OB, Pollack J B (1979) Anthropogenic albedo changes and the earth's climate. Science 206:1363-1368

Shen PY, Beck AE (1991) Least squares inversion of borehole temperature measurements in functional space. J Geophys Res 96:19965-19979

Shen PY, Pollack HN, Huang S, Wang K (1995a) Effects of subsurface heterogeneity on the inference of climate change from borehole temperature data: model studies and field examples from Canada. J Geophys Res 100: 6383-6396

Shen PY, Pollack HN, Shaopeng H (1995b) Inference of ground surface temperature history from borehole temperature data: a comparison of two inverse methods. Abstracts 21st IUGG General Assembly, Boulder, Vol A. Int Union of Geodesy \& Geophysics, Boulder, CO, p 251

Shukla J, Nobre C, Sellers P (1990) Amazonian deforestation and climate change. Science 247:1322-1325

Statistics Canada Census of Agriculture (1992) Use of farm land. Market Analysis Statistic Branch of Alberta Agriculture, Statistics, Ottawa

Taylor AE, Burgess M, J udge AS, Allen VS (1982) Canadian geothermal data collection-northern wells. Earth Physics Branch EMR (Energy, Mines \& Resources), Ottawa Geotherm Ser 13 
Turner BL, Skole D, Sanderson S, Fischer G, Fresco L, Leemans R (1995) Land-use and land-cover change. IGBP Report No. 35, HDP Rep No. 7

Vincent $L$ (1998) A technique for the identification of inhomogeneities in Canadian temperature series. J Clim 11: 1094-1104

Vincent L, Gullett DW (1999) Creation of historic and homogeneous datasets for climate change analyses in Canada.

Editorial responsibility: Brent Yarnal, University Park, Pennsylvania, USA
Int J Climatol (in press)

Wang K, Belton DS, Shen PY, Lewis TJ (1994) Differences in recent ground surface warming in eastern and western Canada: evidence from borehole temperatures. Geophys Res Lett 21:2689-2692

Zhang H, Henderson-Sellers A, M cGuffie K (1996) Impacts of tropical deforestation I: process analysis of local climatic change. J Clim 9:1497-1517

Submitted: September 9, 1998; Accepted: March 23, 1999

Proofs received from author(s): J une 1, 1999 